\title{
Use of chromogenic peptide substrates in the determination of clotting factors II, VII, IX and X in normal plasma and in plasma of patients treated with oral anticoagulants
}

Citation for published version (APA):

van Dieijen-Visser, M. P., van Wersch, J., Brombacher, P. J., Rosing, J., Hemker, H. C., \& van Dieijen, G. (1982). Use of chromogenic peptide substrates in the determination of clotting factors II, VII, IX and X in normal plasma and in plasma of patients treated with oral anticoagulants. Haemostasis, 12(3), 241-255. https://doi.org/10.1159/000214679

Document status and date:

Published: 01/01/1982

DOI:

$10.1159 / 000214679$

Document Version:

Publisher's PDF, also known as Version of record

Please check the document version of this publication:

- A submitted manuscript is the version of the article upon submission and before peer-review. There can be important differences between the submitted version and the official published version of record. People interested in the research are advised to contact the author for the final version of the publication, or visit the DOI to the publisher's website.

- The final author version and the galley proof are versions of the publication after peer review.

- The final published version features the final layout of the paper including the volume, issue and page numbers.

Link to publication

\footnotetext{
General rights rights.

- You may freely distribute the URL identifying the publication in the public portal. please follow below link for the End User Agreement:

www.umlib.nl/taverne-license

Take down policy

If you believe that this document breaches copyright please contact us at:

repository@maastrichtuniversity.nl

providing details and we will investigate your claim.
}

Copyright and moral rights for the publications made accessible in the public portal are retained by the authors and/or other copyright owners and it is a condition of accessing publications that users recognise and abide by the legal requirements associated with these

- Users may download and print one copy of any publication from the public portal for the purpose of private study or research.

- You may not further distribute the material or use it for any profit-making activity or commercial gain

If the publication is distributed under the terms of Article 25fa of the Dutch Copyright Act, indicated by the "Taverne" license above, 


\title{
Original Papers
}

\section{Use of Chromogenic Peptide Substrates in the Determination of Clotting Factors II, VII, IX and X in Normal Plasma and in Plasma of Patients Treated with Oral Anticoagulants}

\author{
M.P. van Dieijen-Visser ${ }^{\mathrm{a}, \mathrm{b}}, J$, van Wersch ${ }^{\mathrm{a}}$, P.J. Brombacher ${ }^{\mathrm{b}}, J$. Rosing ${ }^{\mathrm{c}}$, H.C. Hemker ${ }^{\mathrm{c}}$, \\ $G$. van Dieijen ${ }^{c}$ \\ Departments of a Haematology and ${ }^{b}$ Clinical Chemistry, De Wever Hospital, Heerlen, The Netherlands; \\ c Department of Biochemistry, University of Limburg, Maastricht, The Netherlands
}

Key Words. Factors II, VII, IX, X · Chromogenic assays · Monitoring therapy with oral anticoagulants. Thrombotest . Variation in normal values . Therapeutic ranges

Abstract. Spectrophotometric methods were used to assay the clotting factors II, VII, IX and $\mathrm{X}$ in plasma of 33 subjectively healthy human donors and in plasma of 98 patients receiving long-term oral anticoagulant therapy. In 33 normal subjects the interindividual variations in the plasma activities of the clotting factors II, VII, IX and X are respectively $12.2,21.4,11.0$ and $15.0 \%$. After correction for the assay variations the remaining biological variations are respectively $11.7,21.2,9.7$ and $14.8 \%$.

Plasma from 98 patients receiving long-term anticoagulant therapy was assayed with 'Thrombotest', a clotting test in whole blood introduced by Owren and in these plasmas the activity of each of the vitamin K-dependent factors was assayed with spectrophotometric methods. For the clotting factors IX and VII, novel spectrophotometric methods were applied and the plasma activities thus measured were compared to results obtained with factor IX and VII clotting assays.

Chromogenic activities of the different factors were correlated among each other and with $1 /$ Thrombotest values. When the therapeutic range for Thrombotest values is set between 5 and $12.5 \%$ the corresponding therapeutic ranges for the activity of the factors II, VII, IX and $\mathrm{X}$ are respectively $12.6-36.1,27.0-52.3,23.1-49.3$ and $18.9-36.2 \%$ (expressed as a percentage of the activity in normal pool plasma). The chromogenic assays for the factors II, VII, IX and $\mathrm{X}$ provide the same information on the therapeutic state of the patients in respectively $86.7,78.6,81.6$ and $89.8 \%$ of the cases.

Finally we discuss the suitability of the different assays to monitor oral anticoagulant therapy. 


\section{Introduction}

For several clotting factors spectrophotometric assays, based on the splitting of specific chromogenic substrates, have been introduced [1-3]. Amidolytic cleavage of such a substrate by an activated clotting factor results in the release of $p$-nitroaniline which absorbs at $405 \mathrm{~nm}$. Conditions can be chosen such that the change in absorbance at $405 \mathrm{~nm}$ is proportional to the concentration of the activated enzyme cleaving the synthetic substrate. The chromogenic substrate $\mathrm{S} 2337$ is specific for factor $\mathrm{Xa}$ and is used in this study in the chromogenic assays for the factors IX, X and VII. The chromogenic substrate chromozym $\mathrm{TH}$, specific for thrombin, is used in the factor II chromogenic assay.

Synthesis of the clotting factors II, VII, IX and $\mathrm{X}$ is vitamin $\mathrm{K}$-dependent and activities of these factors in plasma rapidly diminish when oral anticoagulant drugs are administered. Immediately after the start of oral anticoagulant therapy, plasma activities of the four factors start decreasing with velocities depending on their half-life in plasma. Factor VII disappears most rapidly ( $\left.\mathrm{T}^{1 / 2}, 4-6 \mathrm{~h}\right)$ [4], hereafter factor IX $\left(\mathrm{T}^{1 / 2}, 18-30 \mathrm{~h}\right)[4,5]$. The half-lives of factors $X$ and II are about 40-60 and 48-96 h, respectively [4-6]. In patients receiving long-term treatment with oral anticoagulants the clotting activities of the four vitamin $\mathrm{K}$-dependent factors are aimed to be kept at $20 \%$ of normal [7]. The desired level is dependent on medical considerations [7, 8].

The potential application of a chromogenic substrate method in monitoring antivitamin $\mathrm{K}$ treatment has been discussed ever since the introduction of chromogenic substrates in the field of coagulation. The prob- lem of their acceptance is not so much the technical difficulty of devising good spectrophotometric tests but rather the fact that current medical practice has defined therapeutic levels of treatment in terms of overall coagulation tests of the Quick type (e.g. thromboplastin time, Thrombotest) [9]. Now that separate chromogenic tests for the vitamin $\mathrm{K}$ dependent factors are available the problem arises which factor is to be preferred and to which level this factor should be reduced to produce a therapeutic lowering of thrombinforming capacity, without introducing bleeding risks.

In a large trial $(n=2,222)$, van Wijk [10] observed an acceptable correlation between 1/Thrombotest values and factor X chromogenic activity $(r=0.78)$. The therapeutic range for Thrombotest was taken between 5 and $12.5 \%$, the corresponding therapeutic range for factor $\mathrm{X}$ chromogenic activity was 180-300 U/1 (18-30\%) [11]. Poller et al. [12] observed a good agreement between 1/Thrombotest and factor VII chromogenic activity in plasma; percentage agreement in diagnosis was $87.5 \%$.

Until now in most experimental studies the chromogenic activity of only one of the vitamin $\mathrm{K}$-dependent clotting factors has been compared to Thrombotest values [1013] or to the clotting activity of the other vitamin $\mathrm{K}$-dependent factors [10-15]. In the present study the chromogenic activity of all four vitamin $\mathrm{K}$-dependent factors was assayed in healthy human subjects and in patients receiving oral anticoagulant drugs. The chromogenic activities of the vitamin $\mathrm{K}$ dependent factors were correlated both among each other and with $1 /$ Thrombotest. Based on these results we will discuss the suitability of the different assays to monitor oral anticoagulant therapy. 


\section{Materials and Methods}

Materials

Venous blood samples were collected in plastic tubes containing as anticoagulant one volume trisodium citrate $(0.12 \mathrm{~mol} / 1)$ per nine volumes of blood. Plasma was prepared by centrifuging the blood samples at $2,000 \mathrm{~g}$ for $10 \mathrm{~min}$ at room temperature and at $14,000 \mathrm{~g}$ for $15 \mathrm{~min}\left(4^{\circ} \mathrm{C}\right)$ to obtain platelet-poor plasma. Plasma samples were divided into 5 portions and frozen at $-70^{\circ} \mathrm{C}$.

Reference pool plasma (normal plasma) was prepared by pooling platelet-poor plasma samples from 40 subjectively healthy subjects ( 20 men, 20 women). The plasma was frozen at $-70^{\circ} \mathrm{C}$ in small aliquots containing $0.5 \mathrm{ml}$ of the reference pool plasma. During the complete study the same reference pool plasma was used as an internal standard to correct for day. to-day variations.

The chromogenic substrate S2337 (Bz-Ile-Glu (piperidyl)-Gly-Arg-pNA) was obtained from Kabi AB, Stockholm, Sweden. For the factor IX assay one vial (containing $24 \mathrm{mg}$ lyophilized substrate) was dissolved in $12 \mathrm{ml}$ of sterilized distilled water $(2.5 \mathrm{mmol} / 1)$. For the factor VII and X chromogenic assays one vial was dissolved in $20 \mathrm{ml}$ of sterilized distilled water $(1.5 \mathrm{mmol} / 1)$.

Albumin chicken egg (ovalbumin) crystallized and lyophilized salt-free grade $\mathrm{V}$, electrophoretic purity $99 \%$, Sigma No. A-5503.

Factor IX-deficient plasma was obtained from a patient with hemophilia B, (factor IX clotting activity $<1 \%$ ).

Factor VII-deficient plasma was obtained from bovine plasma treated with disopropyl-phosphorofluoridate (DFP) [16].

Tissue thromboplastin was prepared from human brain as described by Owen [17].

Phospholipids: Brain phosphatidylserine was prepared as described by Sanders [18]. Egg-yolk phosphatidylcholine was obtained from Sigma (No. P8640].

PTT reagent for the factor IX clotting assay was obtained from Roche (Art. No. 0740152). This reagent contains a brain extract serving as a thrombocyte substitute and takes care of complete activation of factor XII (Hageman factor) and can be used to measure a decreased activity of the intrinsic system.

Procedures

Thrombotest (Nyegaard \& Co., Oslo, Norway) was performed according to Owren [9]. The therapeutic range: $179-192$ s, e.g., between 5 and $12.5 \%$. Plasmas from patients who just started therapy or were withdrawn from therapy were excluded from the study.

Proteins: Bovine factor $\mathrm{X}$ was prepared according to Fujikawa et al. [19]. The factor X preparations were homogenous and pure as determined by gel electrophoresis in the presence of sodium dodecyl sulfate (SDS). The specific activities of these preparations, as determined with a clotting assay, were equal to those reported by Fujikawa et al. [19].

Bovine contact product was prepared according to Nossel [20] and further purified by heparin-agarose affinity chromatography as suggested by Østerud and Rapaport [21]. Contact product was applied to the heparin-agarose column $(1.5 \times 15 \mathrm{~cm})$ in a buffer containing $0.05 \mathrm{M}$ sodium acetate and $0.3 \mathrm{M} \mathrm{NaCl}$ at $\mathrm{pH}$ 5.5 eluted with a linear gradient of $0.3-1.0 \mathrm{M} \mathrm{NaCl}$ in $0.05 \mathrm{M}$ sodium acetate at $\mathrm{pH}$ 5.5.

Phospholipid vesicle preparation: Single bilayer vesicle solutions of a mixture of brain phosphatidylserine and egg-yolk phosphatidylcholine $(25 / 75 \mathrm{w} / \mathrm{w})$ were prepared according to De Kruijff et al. [22] by sonication for $10 \mathrm{~min}$ in $50 \mathrm{mM}$ Tris- $\mathrm{HCl}, 175 \mathrm{mM}$ $\mathrm{NaCl}$ at $\mathrm{pH}$ 7.9. Sonication was performed using a MSE Mark II $150 \mathrm{~W}$ ultrasonic disintegrator set at 10 $\mu \mathrm{m}$ peak-to-peak amplitude. After sonication no $\mathrm{pH}$ adjustment was needed.

Spectrophotometric assay for factor II: A test kit commercially available from Boehringer, Mannheim, FRG, was used. In this assay the prothrombin present in a plasma sample is quantitatively converted to thrombin by a complex of factors $\mathrm{Xa}, \mathrm{Va}$, phospholipids and calcium. After activation of prothrombin the amount of thrombin present is determined with the chromogenic substrate chromozym TH.

Spectrophotometric assay for factor X: A commercially available test kit was used (Kabi AB, Stockholm, Sweden). In this assay, factor $\mathrm{X}$ in a plasma sample is quantitatively converted to factor $\mathrm{Xa}$ with the factor $\mathrm{X}$-activating enzyme from Russell's viper venom. The amount of factor $\mathrm{Xa}$ formed is determined with S2337, a chromogenic peptide substrate specific for factor Xa.

Spectrophotometric assay for factor IX: The assay first described by Tans et al. [23] was used. The assay involves the following steps: (1) conversion of plasma factor IX to factor IXa by purified factor XIa (contact product); (2) incubation of factor IXa with factor X, phospholipids and $\mathrm{Ca}^{2+} ;$ (3) addition of EDTA to stop of factor Xa formation by IXa; (4) determination of 
factor Xa present from the rate of hydrolysis of $\$ 2337$; (5) calculation of the amount of factor Xa present, using a calibration curve made with reference pool plasma.

Since the Uvicon 810 (Kontron) spectrophotometer used in our studies is not as sensitive as the Aminco DW2 used by Tans et al. [23] it was necessary to modify the procedure such that higher absorbance changes were obtained. The details of the method are as follows: in the first step $90 \mu \mathrm{l}$ buffer with ovalbumin (175 mM NaCl, $50 \mathrm{mM}$ Tris- $\mathrm{HCl}, \mathrm{pH} 7.9$ at $25^{\circ} \mathrm{C}$, $0.5 \mathrm{mg} / \mathrm{ml}$ ovalbumin), $15 \mu \mathrm{l} \mathrm{CaCl}_{2}(0.1 \mathrm{M}), 15 \mu \mathrm{l}$ $(0.225 \mathrm{mg}$ ) factor XIa (contact product) and $30 \mu \mathrm{l}$ plasma (dilution 1:10) incubated at $37^{\circ} \mathrm{C}$ during $25 \mathrm{~min}$. From this mixture $100 \mu \mathrm{l}$ is sampled to a mixture, prewarmed at $37^{\circ} \mathrm{C}$ for $5 \mathrm{~min}$, containing $200 \mu \mathrm{l}$ of buffer with ovalbumin, $100 \mu \mathrm{l}$ factor $\mathrm{X}(1 \mu \mathrm{M})$ and $100 \mu \mathrm{C} \mathrm{Ca}^{2+}$ phospholipid mixture $(500 \mu \mathrm{M}$ phospholipid vesicles and $50 \mathrm{mMC} \mathrm{Ca}{ }^{2+}$. Factor $\mathrm{Xa}$ formation is stopped by transfer of $0.4 \mathrm{ml}$ sample to a cuvette containing $0.55 \mathrm{ml}$ of buffer with ovalbumin, containing $20 \mathrm{mM}$ EDTA.

Finally, $50 \mu \mathrm{l} \mathrm{S} 2337(2.5 \mathrm{mM})$ is added and the change in absorbance at $405 \mathrm{~nm}$ is measured. The amount of factor IX in the plasma sample is read from a calibration curve made with varying amounts of the reference pool plasma (fig. 1). A new reference curve was made each time the assay was used in order to correct for day-to-day variations. All measurements were corrected for a reagent blank $(\triangle \mathrm{A} 405 / \mathrm{min}$ obtained without plasma).

Spectrophotometric assay for factor VII: The procedure first described by Seligsohn et al. [13] was used, modified as follows: in a first step the plasma sample $(40 \mu l$, dilution $1: 100)$, containing factor VII, was incubated with tissue thromboplastin $(10 \mu \mathrm{l}), \mathrm{CaCl}_{2}$ $0.1 M(20 \mu \mathrm{l})$, buffer with ovalbumin as described for the factor IX assay $(110 \mu \mathrm{l})$ and a trace of factor Xa $(1 \mathrm{nM}, 20 \mu \mathrm{l})$ to allow quantitative conversion of factor VII to factor VIIa $\left(5 \mathrm{~min}\right.$ at $\left.37^{\circ} \mathrm{C}\right)$. Hereafter the factor $\mathrm{X}$ activation reaction was started by the addition of factor $X(10 \mu \mathrm{M}, 10 \mu \mathrm{l})$. After $4 \mathrm{~min}$ of factor $\mathrm{Xa}$ formation the reaction is stopped by addition of buffer with ovalbumin, containing $20 \mathrm{mM}$ EDTA $(0.7 \mathrm{ml})$. In the last step, factor $\mathrm{Xa}$ activity is measured by adding $0.1 \mathrm{ml} \$ 2337(1.5 \mathrm{mM})$ and determining the initial rate of cleavage of this chromogenic substrate. The amount of factor VII activity was read from a calibration curve of the reference pool plasma. A new calibration curve was made each time the assay was used. Due to the presence of a trace of factor $\mathrm{Xa}$ in the preincubation reaction no lag period in the factor Xa formation as reported by Seligsohn et al. [13] was observed. Another difference is that bovine factor $\mathrm{X}$ rather than human factor $\mathrm{X}$ is used in our assay. The concentration of factor $X$ in the assay is $0.47 \mu M$, equal to three times the plasma factor $X$ concentration. In contrast to the results of Seligsohn et al. [13] with human factor $\mathrm{X}$, we found low blank values in the absence of plasma (reagent blank). The reagent blank was $0.001 \triangle \mathrm{A} 405 / \mathrm{min}$, that is about $1.5 \%$ of the $\triangle \mathrm{A} 405 / \mathrm{min}$ found for the reference pool plasma (table II). All measurements were corrected for this reagent blank.

Factor VII clotting assay was performed according to Nemerson and Clyne [16].

Factor IX clotting assay: $0.1 \mathrm{ml}$ factor IX-deficient plasma, $0.1 \mathrm{ml}$ test patient plasma (1:10 dilution) and $0.1 \mathrm{ml}$ PTT reagent from Roche were incubated at $37^{\circ} \mathrm{C}$ for $5 \mathrm{~min}$. Hereafter $0.025 \mathrm{M} \mathrm{Ca}^{2+}$ was added and the clotting time was measured [24].

Statistical analysis of the data: The significance of differences between two values was tested by a paired Student's $t$ test [25]. Rank coefficients of correlation were calculated according to the method of Jonge [25] and Spearman [26]. The rank coefficient of correlation is a distribution-free, nonparametric coefficient of correlation.

\section{Results}

\section{Analytical Variables}

The linearity of the assays: The linearity of the different chromogenic assays was investigated by testing dilutions of the reference pool plasma and of a patient receiving oral anticoagulant therapy. Figure 1 demonstrates the results for factor IX.

Within- and Between-Assay Precision of the different assays is shown in table I. Within-assay precision was estimated by assaying two dilutions of the reference pool plasma (100 and 25\%) 10 times each. Variations are expressed as a percentage of the mean activity in plasma. Between-assay precision of the chromogenic assays was determined by use 


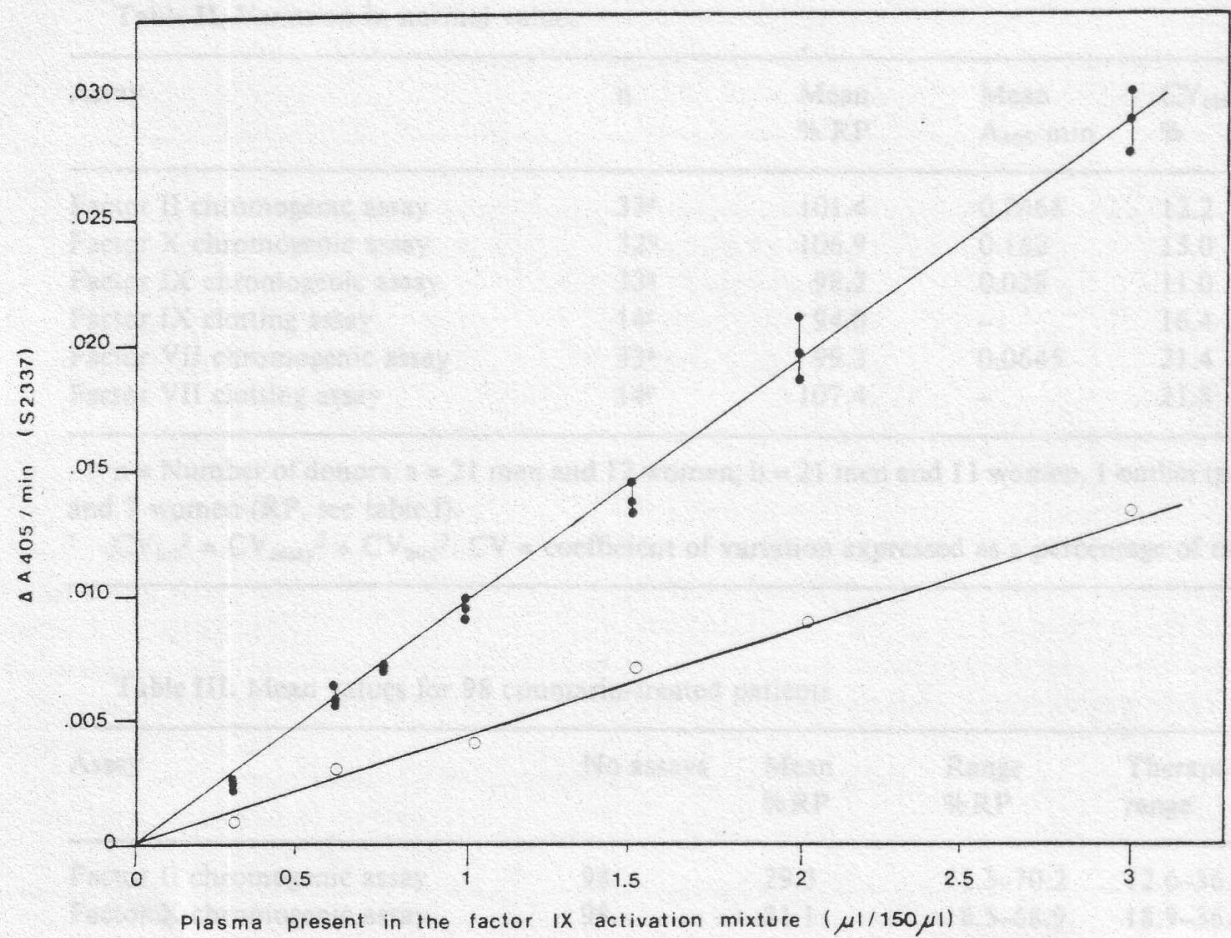

Fig. 1. Calibration curve of the factor IX chromogenic assay. Different dilutions of the reference pool plasma $(\bullet)$. Different dilutions of plasma from a patient receiving oral anticoagulants $(0)$.

Table I. Within- and between-assay precision of various assays

\begin{tabular}{|c|c|c|c|}
\hline \multirow[t]{2}{*}{ Assay } & \multicolumn{2}{|c|}{ Within-assay variation, $\%$} & \multirow{2}{*}{$\begin{array}{l}\text { Between-assay } \\
\text { variation, } \% \\
100 \% \text { RP }\end{array}$} \\
\hline & $100 \% \mathrm{RP}$ & $25 \% \mathrm{RP}^{1}$ & \\
\hline Factor II chromogenic activity & 3.6 & 5.4 & 6.0 \\
\hline Factor $\mathrm{X}$ chromogenic activity & 3.0 & 4.3 & 5.0 \\
\hline Factor IX chromogenic activity & 5.1 & 6.7 & 8.8 \\
\hline Factor IX clotting activity & 13.0 & 6.2 & - \\
\hline Factor VII chromogenic activity & 3.5 & 5.6 & 5.8 \\
\hline Factor VII clotting activity & 5.1 & 3.7 & - \\
\hline Thrombotest ${ }^{2}$ & $7.4(40 \% \mathrm{RP})$ & $3.8(25 \% \mathrm{RP})$ & $5.1(25 \% \mathrm{RP})$ \\
\hline
\end{tabular}

Coefficient of variation: standard deviation as a percentage of the mean.

Within-assay variation: coefficient of variation for chromogenic measurements on the same day.

Between-assay variation: coefficient of variation for chromogenic measurements on different days.

$R P=$ reference pool plasma, obtained from 40 subjectively healthy donors ( 20 men, 20 women).

: Thrombotest is insensitive to values larger than $30-40 \%$. 
Table II. Variation in normal values

\begin{tabular}{|c|c|c|c|c|c|}
\hline Assay & $\mathrm{n}$ & $\begin{array}{l}\text { Mean } \\
\% \text { RP }\end{array}$ & $\begin{array}{l}\text { Mean } \\
\mathrm{A}_{405} / \mathrm{min}\end{array}$ & $\begin{array}{l}\mathrm{CV}_{\text {tot }} \\
\%\end{array}$ & $\begin{array}{l}\mathrm{CV}_{\text {biol }}{ }^{1} \\
\%\end{array}$ \\
\hline Factor II chromogenic assay & $33^{a}$ & 101.4 & 0.2468 & 12.2 & 11.7 \\
\hline Factor X chromogenic assay & $32^{b}$ & 106.9 & 0.162 & 15.0 & 14.8 \\
\hline Factor IX chromogenic assay & $33^{\mathrm{a}}$ & 98.2 & 0.028 & 11.0 & 9.7 \\
\hline Factor IX clotting assay & $14^{c}$ & 94.0 & - & 16.4 & 10.0 \\
\hline Factor VII chromogenic assay & $33^{\mathrm{a}}$ & 99.3 & 0.0645 & 21.4 & 21.2 \\
\hline Factor VII clotting assay & $14^{\mathrm{c}}$ & 107.4 & - & 21.8 & 21.2 \\
\hline
\end{tabular}

$n=$ Number of donors; $a=21$ men and 12 women; $b=21$ men and 11 women, 1 outlier $(p<0.01) ; c=7$ men and 7 women (RP, see table I).

$1 \mathrm{CV}_{\text {tot }^{2}}{ }^{2} \mathrm{CV}_{\text {assay }}{ }^{2}+\mathrm{CV}_{\text {biol }}{ }^{2} \cdot \mathrm{CV}=$ coefficient of variation expressed as a percentage of mean.

Table III. Mean values for 98 coumarin-treated patients

\begin{tabular}{llllll}
\hline Assay & No assays & $\begin{array}{l}\text { Mean } \\
\% R P\end{array}$ & $\begin{array}{l}\text { Range } \\
\text { \%RP }\end{array}$ & $\begin{array}{l}\text { Therapeutic } \\
\text { range agreement } \\
\text { with TT }\end{array}$ \\
\hline Factor II chromogenic assay & 98 & 29.3 & $11.3-70.2$ & $12.6-36.1$ & 86.7 \\
Factor X chromogenic assay & 98 & 31.1 & $18.5-68.9$ & $18.9-36.2$ & 89.8 \\
Factor IX chromogenic assay & 98 & 41.7 & $19.6-96.3$ & $23.1-49.3$ & 81.6 \\
Factor VII chromogenic assay & 98 & 45.0 & $15.6-80.3$ & $27.0-52.3$ & 78.6 \\
Thrombotest & 98 & 10.4 & $5.0-25.0$ & $5.0-12.5$ & - \\
\hline
\end{tabular}

1 In comparing two different tests, results were divided into three categories: therapeutic, underdosed and overdosed. The percentage agreement between Thrombotest and a chromogenic assay represents the percentage of cases in which the two different tests result in the same diagnosis with relation to oral anticoagulant therapy. (RP, see table I).

of the reference pool plasma, stored in small portions at $-70^{\circ} \mathrm{C}$. On 10 subsequent days one portion was assayed, from which the between-assay variation could be calculated.

\section{Clinical Results}

Variation in normal values: We assayed factor II, VII, IX and X chromogenic activities in 33 healthy volunteers ( 21 men, 12 women). The total variation (interindividual variation) and the biological variation of the normal values are presented in table II. Espe- cially for factor IX a rather small biological variation (less than 10\%) is observed. For the factors IX and VII clotting activity was also assayed in 14 normal plasmas $(7 \mathrm{men}, 7$ women). Especially for factor IX a much larger variation in the clotting activity (expressed as a percentage of the same reference pool as used in the chromogenic assay) is observed compared to results obtained with the spectrophotometric method (table II).

Comparison of chromogenic activity of vitamin $K$-dependent factors and Thrombotest 
Table IV. Correlation between the various chromogenic assays and Thrombotest (TT)

\begin{tabular}{llll}
\hline & 98 coumarin-treated patients & $\begin{array}{c}101 \text { coumarin-treated patients } \\
\text { and } 33 \text { normal persons }\end{array}$ \\
\hline Assays & $\mathrm{T}_{\mathrm{R}}$ & $\mathrm{r}$ & $\mathrm{T}$ \\
\hline TI vs. factor II & 0.88 & $0.83<0.88<0.92$ & - \\
TT vs. factor X & 0.78 & $0.77<0.84<0.89$ & - \\
TI vs. factor IX & 0.72 & $0.67<0.78<0.85$ & - \\
TT vs. factor VII & 0.72 & $0.66<0.76<0.83$ & - \\
& & & \\
Factor II vs. factor X & 0.78 & $0.76<0.83<0.88$ & $0.94<0.96<0.97$ \\
Factor II vs. factor IX & 0.64 & $0.62<0.73<0.81$ & $0.89<0.92<0.94$ \\
Factor II vs. factor VII & 0.65 & $0.52<0.65<0.75$ & $0.82<0.87<0.96$ \\
Factor IX vs. factor X & 0.67 & $0.74<0.82<0.88$ & $0.89<0.92<0.94$ \\
Factor IX vs. factor VII & 0.70 & $0.58<0.70<0.79$ & $0.81<0.86<0.89$ \\
Factor X vs. factor. VII & 0.55 & $0.47<0.61<0.72$ & $0.84<0.88<0.91$
\end{tabular}

$\Gamma_{R}:$ rank coefficient of correlation, i.e. a distribution free (nonparametric) determination of the coefficient of correlation [cf. 25, 26].

r: coefficient of correlation; the $95 \%$ confidence limits are also given.

$\mathrm{n}=98: 75$ men and 23 women.

$n=134: 98$ men and 36 women.

values in 98 patients on long-term anticoagulant therapy: From the De Wever Hospital in Heerlen we chose 98 patients receiving longterm oral anticoagulant treatment $(75$ men, 23 women) and compared the Thrombotest values to results obtained with the four different spectrophotometric methods, used to assay the plasma activities of the four vitamin $\mathrm{K}$-dependent factors. Table III summarizes the results and in table IV the coefficients of correlation between the different assays are given. The $95 \%$ confidence limits of the coefficients of correlation are shown. We also computed the rank coefficient of correlation, a distribution-free determination of the coefficient of correlation, according to Spearman [26]. This rank coefficient of correlation is not influenced by the range of the measurements. As can be seen from table III, activities of the clotting factors are distrib- uted over different ranges. In this case a rank coefficient of correlàtion will better reflect the correlation between the different assays, compared to the normal coefficient of correlation.

Figure $2 a-d$ shows the correlation between $1 /$ Thrombotest and the chromogenic activity of the factors II, VII, IX and X. The best correlation was observed between 1/Thrombotest and factor II chromogenic activity $(r=0.88)$.

The 'therapeutic range' is a distinct degree of drug-induced inhibition of the coagulation, which is regarded as protecting against thrombus formation, according to previous clinical experiences the range for the Thrombotest as routinely used in our laboratory is between 179 and 92 s, i.e. betweèn 5 and $12.5 \%$. When the therapeutic range for Thrombotest is set between 5 and $12.5 \%$ the 


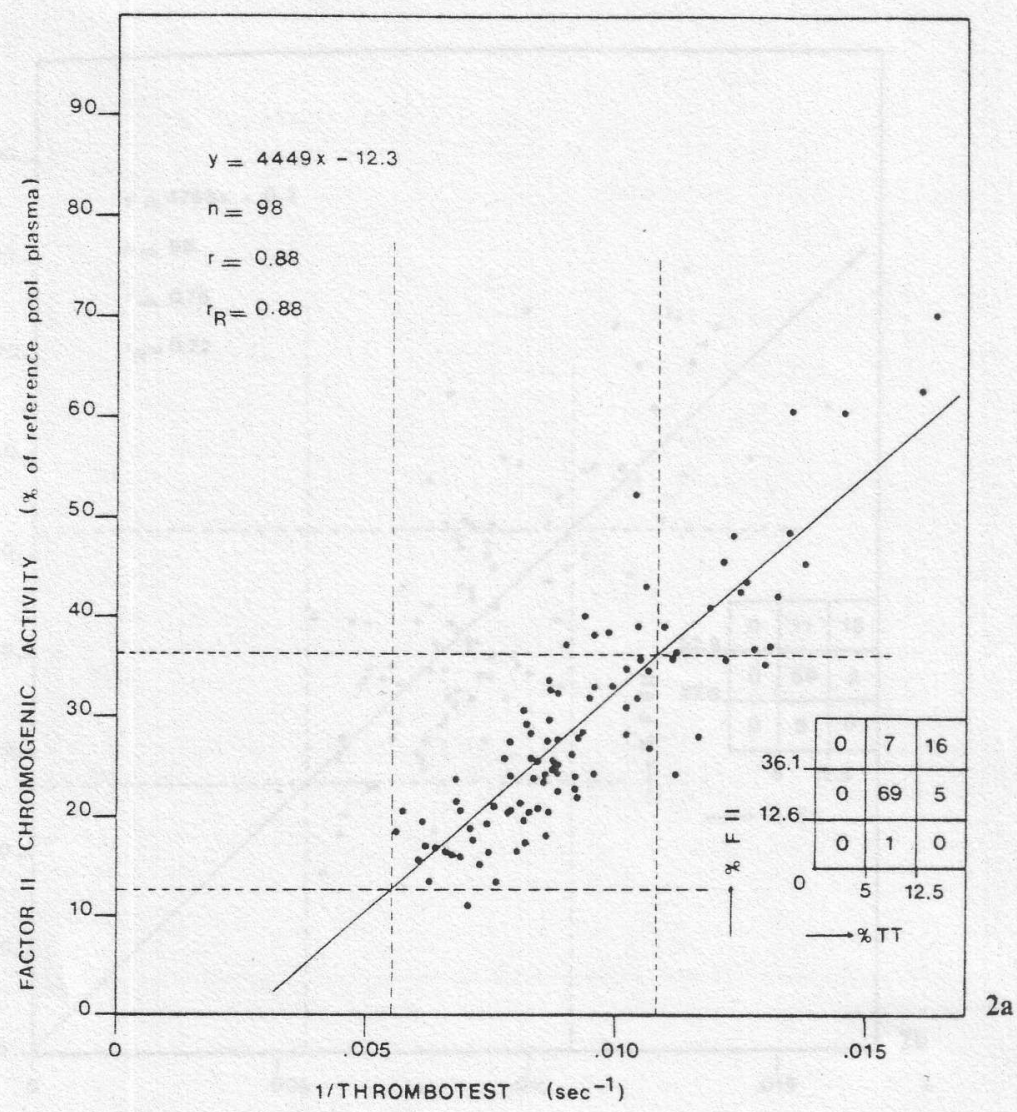

Fig. 2. a-d Correlation between 1/Thrombotest and factor II, VII, IX and X chromogenic activities in patients receiving oral anticoagulant therapy.

therapeutic ranges for the factors II, VII, IX and $\mathrm{X}$ can be calculated (table III).

Comparison of chromogenic assays and clotting assays: For part of the plasma samples, factor VII and factor IX plasma clotting activities were measured with clotting assays and the results were compared to the results obtained with the chromogenic assays. Correlation was good between factor VII chromogenic assay and factor VII clotting assay $(r=0.94$, fig. 3 ). However, there was a significant difference between the values obtained for both assays in this group of patients (paired t test, $p<0.05$ ). The factor VII clotting activity was consistently lower than the factor VII chromogenic activity. Correlation between factor IX chromogenic activity and factor IX clotting activity was less good $(r=$ $0.88, n=38$, fig. 4 ). This is probably caused by the insensitivity of the factor IX clotting assay compared to the factor VII clotting assay. There was no significant difference between the results obtained with the factor IX clotting assay and the results obtained with the factor IX chromogenic assay (fig. 4) ( $p<$ 0.05 ). 


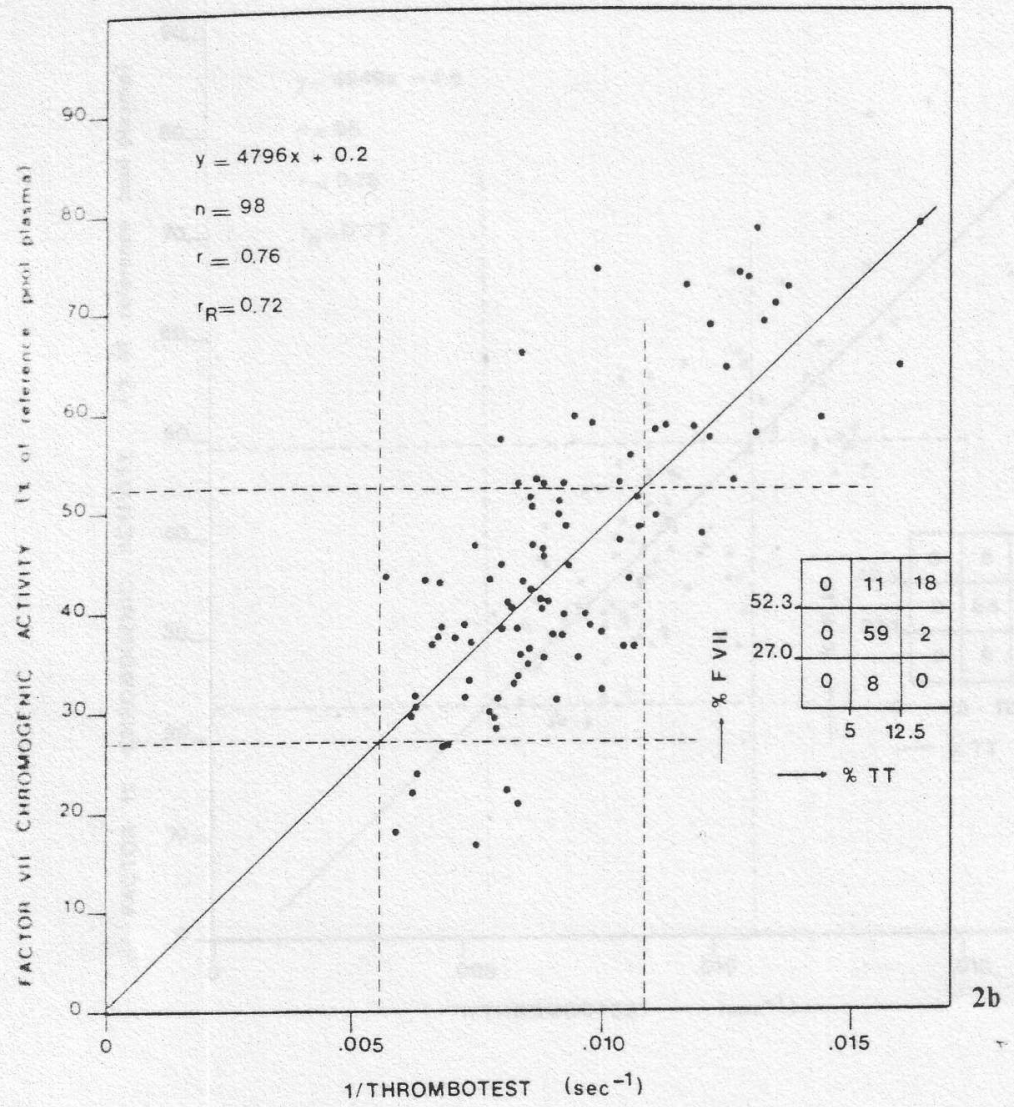

\section{Discussion}

The carboxylation of des- $\gamma$-carboxy factors II. VII, IX or $X$ to their biologically active $7 y$ mogens is vitamin $\mathrm{K}$ dependent and thus treatment of patients with vitamin $\mathrm{K}$ antagonists will result into decreased levels of the carboxylated forms of the four vitamin K-dependent clotting factors. Thrombinforming capacity will be decreased under these circumstances and this principle underhes oral anticoagulant therapy for patients with cardiovascular and thromboembolic disorders. At present the routine monitoring of oral anticoagulant therapy occurs with thromboplastin time tests like Thrombotest for example. These clotting assays involve the activation reactions of the extrinsic cascade, resulting in the formation of a fibrin clot. Reduction of the concentration of the vitamin $\mathrm{K}$-dependent clotting factors reduces the rate of some of the activation reactions and the cumulative effects are measured.

Since the introduction of chromogenic peptide substrates for thrombin and factor $\mathrm{Xa}$, spectrophotometric methods have been developed to determine the activity of each of the vitamin $\mathrm{K}$-dependent clotting factors individually. The possible application of chromogenic substrates to monitor oral anti- 


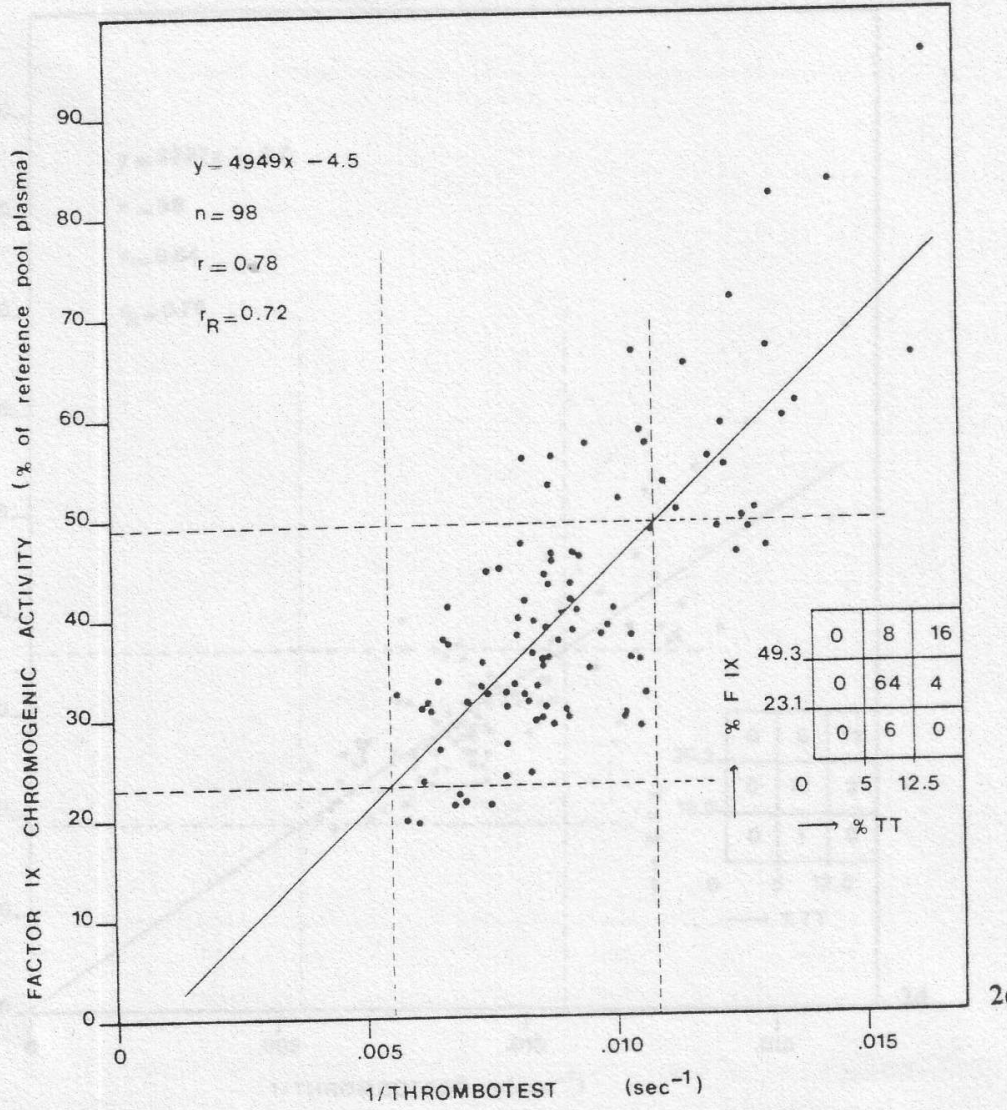

For legend see p. 248.

coagulant therapy has been suggested ever since $[3,11-13,27,28]$. One of the advantages of the use of chromogenic substrates to monitor oral anticoagulant therapy is that spectrophotometric methods can be automated, resulting in considerably smaller assay variations. When the automated analyzer is interfaced with a computer the results for a test sample can be translated into a dosage by a computer-programmed dosage scheme [11].

Presently a much discussed question is which of the vitamin K-dependent factors should be chosen to monitor oral anticoagulant therapy. Before there can be thought of replacing Thrombotest by a spectrophoto- metric assay it has to be evaluated very carefully which of the four factors, if any, should be preferred.

In table $\mathrm{V}$ we give several criteria that can be used to evaluate to suitability of the different chromogenic tests to monitor oral anticoagulant therapy: (1) The assay used should be simple; (2) The biological variation in the normal plasma activity should be small; (3) The biological half-life of the clotting factor should be short, because plasma activities of clotting factors that have a short half-life better reflect the momentary state of anticoagulation of the patient; (4) It should be possible to define a zone of optimal anticoagulation. Up till now this has been defined in 


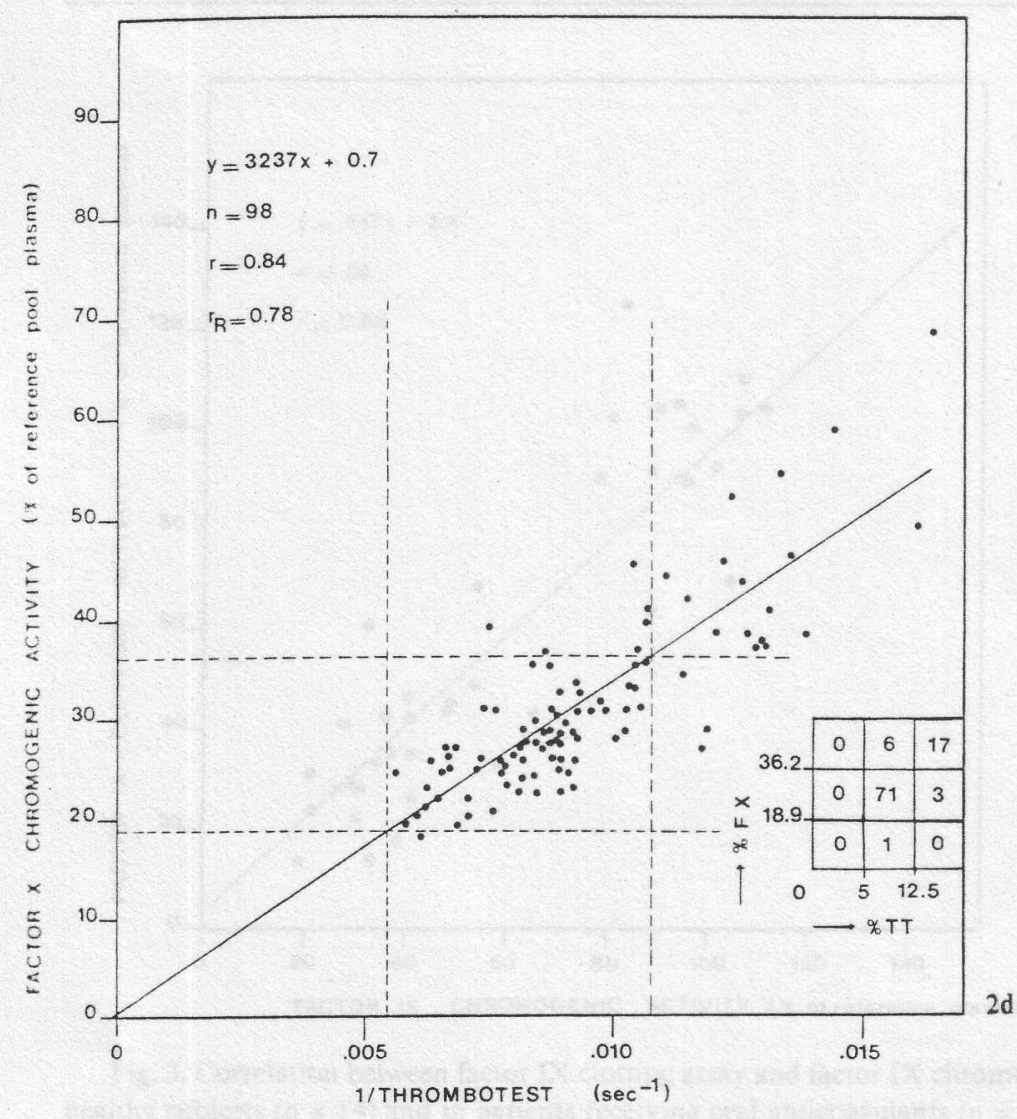

terms of Thrombotest values. This, however, is an overall test and it is actually unknown which factor(s) is (are) responsible for therawutic effects and bleeding risk. Therefore, linally a large prospective double-blind study to compare the results obtained with the best chromogenic assay and the conventional Thrombotest should be performed.

\section{Irsay lariation and Simplicity of the issay.}

The chromogenic assays for factors II and $\checkmark$ involve only a few pipetting steps and can * completed within $5 \mathrm{~min}$. In contrast the 2.w for factor IX in its present form reres long incubation times. Further re- search could lead to simplification of this assay. Inclusion of factor VIIIa in the assay would shorten the assay time, because it stimulates the rate of factor $\mathrm{X}$ activation and therefore measurable amounts of factor $\mathrm{Xa}$ would be produced faster. The larger assay variation for factor IX (table I), compared to assay variations of $3-3.5 \%$ for the factors II, VII and X may be a consequence of the fact that the factor IX assay requires longer incubation times and produces smaller $a b$ sorbance changes than the other assays. Automation of the assay could reduce this variation. Automation of the factor $X$ assay reduced the assay variation from 3.5 to $1.9 \%[10]$. 


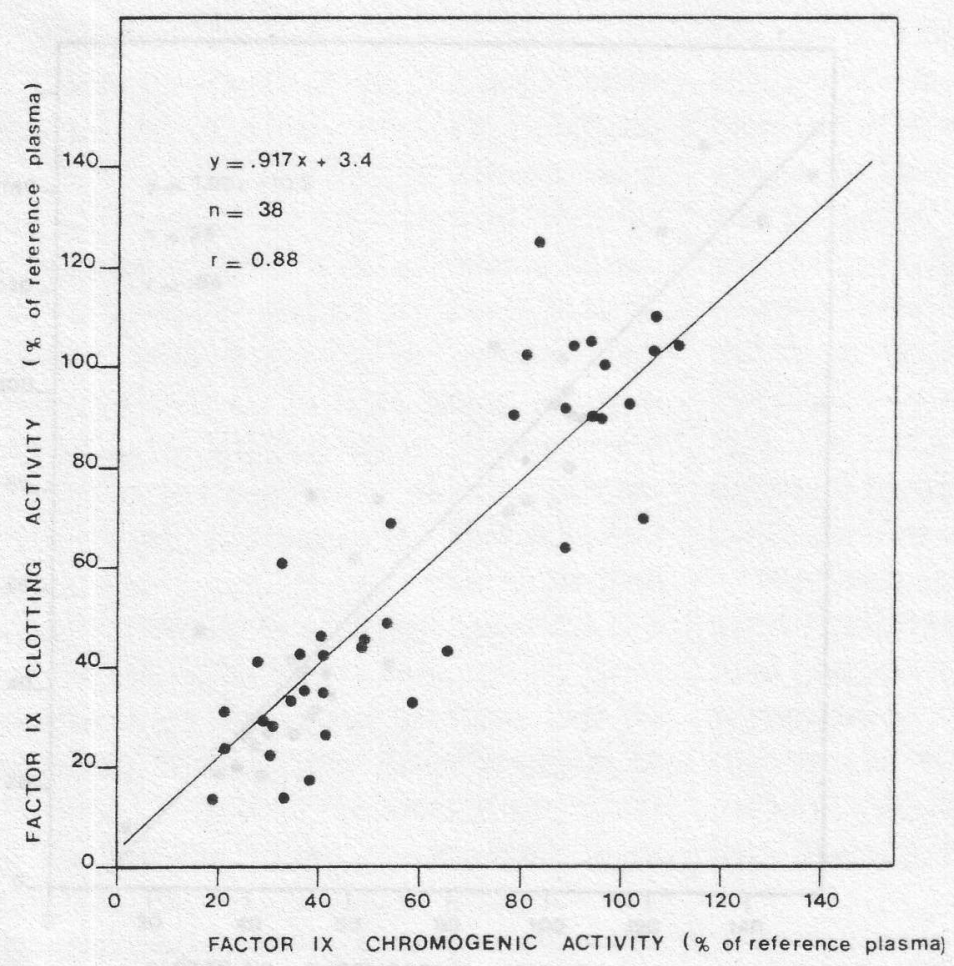

Fig. 3. Correlation between factor IX clotting assay and factor IX chromogenic assay for factor IX activity in healthy subjects $(n=14)$ and in patients receiving oral anticoagulants $(n=24)$.

Table V. Criteria to evaluate the suitability of different chromogenic assays to monitor oral anticoagulant therapy

\begin{tabular}{llllll}
\hline Assay & $\begin{array}{l}\text { Assay } \\
\text { variation, } \%\end{array}$ & $\begin{array}{l}\text { Simplicity } \\
\text { of the assay }\end{array}$ & $\begin{array}{l}\text { Biological } \\
\text { half-life, } \mathrm{h}\end{array}$ & $\begin{array}{l}\text { Biological } \\
\text { variation, \% }\end{array}$ & $\begin{array}{l}\text { Relation } \\
\text { to TT, } \mathrm{r}_{\mathrm{R}}\end{array}$ \\
\hline Factor II chromogenic assay & 3.6 & 2 & $48-96$ & 11.7 & 0.88 \\
Factor X chromogenic assay & 3.0 & 3 & $40-60$ & 14.8 & 0.78 \\
Factor IX chromogenic assay & 5.1 & 5 & $18-30$ & 9.7 & 0.72 \\
Factor VII chromogenic assay & 3.5 & 4 & $4-6$ & 21.2 & 0.72 \\
Thrombotest & 3.8 & 1 & - & - & - \\
\hline
\end{tabular}

Ideal assay: one-step; small assay variation; short biological half-life; small biological variation.

1 Simplicity of the assays is graded on a scale from 1 to 5 , where 1 can be carried out fast in a few steps, whereas 5 is a more complicated and time-consuming assay. 


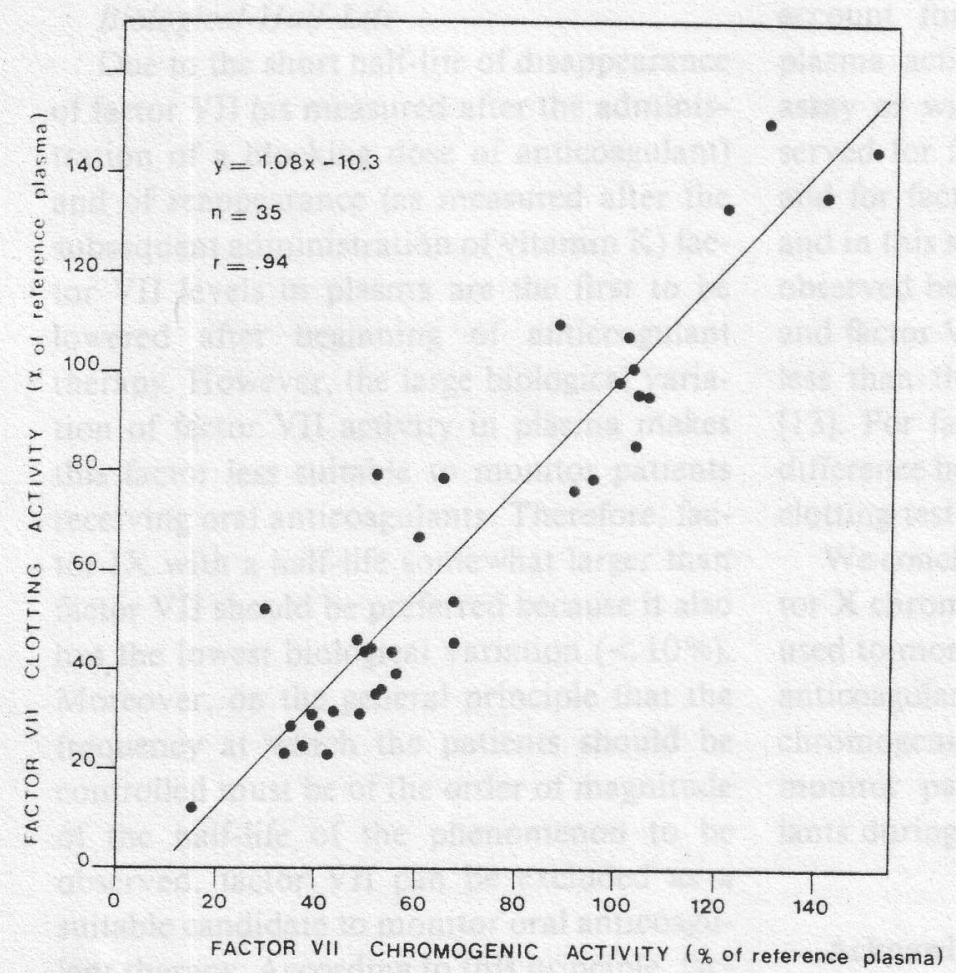

Fig. 4. Correlation between factor VII clotting assay and factor VII chromogenic assay for factor VII activity in healthy subjects $(n=14)$ and in patients receiving oral anticoagulants $(n=21)$.

An advantage of Thrombotest remains that it can be carried out in whole blood whereas plasma is needed in the chromogenic assays. Therefore, Thrombotest is especially surtable in urgent situations, since one test can be performed within $2 \mathrm{~min}$. Although clouing assays can be mechanized, which requires special apparatus, chromogenic assays can be implemented on automated spectrophotometers already present in the clinical laboratory.

\section{Biological lariation}

The biological variations in the activity in fisma of the factors $X$ and VII, measured with chromogenic assays and estimated from the activity in plasma of 33 healthy subjects, show great similarities with results obtained by van Wijk et al. [11] for factor $\mathrm{X}$ and by Seligsohn et al. [13] for factor VII. The activity of the factors II and IX in 'normal' plasma, measured with a chromogenic assay are published here for the first time. For factor IX the smallest biological variation is found (less than 10\%) and the largest biological variation is found for factor VII (about 22\%). Choice of a factor (like IX) with a small biological variation is preferable since a reduction in activity of that factor (as a result of anticoagulant therapy), more accurately reflects a change in synthesis rate. 


\section{Biological Half-Life}

Due to the short half-life of disappearance of factor VII (as measured after the administration of a blocking dose of anticoagulant) and of reappearance (as measured after the subsequent administration of vitamin $\mathrm{K}$ ) factor VII levels in plasma are the first to be lowered after beginning of anticoagulant therapy. However, the large biological variation of factor VII activity in plasma makes this factor less suitable to monitor patients receiving oral anticoagulants. Therefore, factor IX with a half-life somewhat larger than factor VII should be preferred because it also has the lowest biological variation $(<10 \%)$. Moreover, on the general principle that the frequency at which the patients should be controlled must be of the order of magnitude of the half-life of the phenomenon to be observed, factor VII can be excluded as a suitable candidate to monitor oral anticoagulant therapy. According to this principle, factors $I I$ and $X$ are not suitable to monitor patients receiving oral anticoagulants for only a short period of time [Hemker and van Dam-Mieras, unpublished results]. The coefficient of correlation that we found between the reciprocal of Thrombotest and factor $\mathrm{X}$ chromogenic activity is comparable with that reported by Bergström and Egberg [28] and by van Wijk et al. [11]. The therapeutic range for Thrombotest also compares well with the results obtained by van Wijk et al. [11].

Poller et al. [12] observed a percentage agreement in diagnosis, assessed with Thrombotest and factor VII chromogenic activity of $87.5 \%$ in patients receiving longterm anticoagulant therapy.

Treatment with vitamin $\mathrm{K}$ antagonists results in the appearance of partly carboxylated factor II, VII, IX and X molecules in the circulation. Partly carboxylated molecules may account for the significant differences in plasma activities measured with a clotting assay or with a chromogenic assay, as observed for factor X by van Wijk et al. [11], and for factor VII by Selighsohn et al. [13] and in this study. However, the difference we observed between factor VII clotting activity and factor VII chromogenic activity is much less than that observed by Seligsohn et al. [13]. For factor IX we found no significant difference between activities measured with a clotting test or with a chromogenic assay.

We conclude that factor II but also the factor X chromogenic activity in plasma can be used to monitor patients receiving long-term anticoagulant therapy, whereas factor IX chromogenic activity should be preferred to monitor patients receiving oral anticoagulants during a short period of time.

\section{Acknowledgements}

We thank Truus Janssen-Claessen for the preparation of factor X, contact product and tissue factor and for performing the factor VII clotting measurements.

\section{References}

1 Aurell, L.; Friberger, P.; Karisson, G.; Claeson, G.: A new sensitive and highly specific chromogenic substrate for factor Xa. Thromb. Res. 11: 595 (1977).

2 Friberger, P.; Lenne, L.: A chromogenic factor X assay with new standardized reagents. Thromb. Haemostasis 42: 54 (1979).

3 Kirchof, B.R.J.; Muller, A.D.; Vermeer, C.; Hemker, H.C.: Control of anticoagulant therapy with a chromogenic substrate. Haemostasis $8: 1-7$ (1979).

4 Hjort, P.F.; Egeberg, O.; Mikkelsen, S.: Turnover of prothrombin. Factor VII and factor IX in a patient with haemophilia A. Scand. J. clin. Lab. Invest. 13: 668 (1961).

5 Loeliger, E.A.; Hensen, A.: Substitution therapy in 
haemophilia B. Thromb. Diath. haemorrh. 6: 391 1.961).

Bachmann. F.: Duckert, F.; Geiger, H.; Baer, P.; holler: Differentiation of the factor VII complex. siudies on the Stuart Prower factor. Thromb. Diath haemorrh. 1: 169 (1937).

Lochiger.E.A.: Esch, B. van der; Mattern, M.J.; Brabander. A.S.A.: Behaviour of factors II, VII, and $X$ and $X$ during long-term treatment with coumarin. Thromb. Diath. haemorrh. 9: 74 (1963).

- Aarmier. F.J.; Spitell, J.A.; Thompson, J.J.; (7) ien. C.A.: Effect of oral anticoagulants on facas III. IX. X and II. Archs intern. Med. 115:667 $1965)$.

(1) wren, P.A.: Thrombotest, a new method for conirolling anticoagulant therapy. Lancet ii.: 754-758 (1959).

3ik. E.M. van: Factor $\mathrm{X}$ and its behaviour in anti-bitamin $K$ treatment and other deficiency siates; thesis Amsterdam (1980).

if Wyk. E.M. van; Kahlé, L.H.; Cate, J.W. ten: Mechanized amidolytic technique for determination if factor $X$ and factor $X$ antigen, and its applicawon to patients being treated with oral anticoaguHnis. Clin. Chem. 26: 885-890 (1980).

Poller. L.; Thombon, J.M.; Bodzenta, A.; Easton, i C.: Latallo. Z.S.; Chmielewska, J.: An assessment of an amidolytic assay for factor VII in the taburatory control of oral anticoagulants. $\mathrm{Br}$. J. Haemat. 49: 69-75 (1981).

i : Scligsohn, U.: Osterud, B.; Rapaport, S.I.: Coupled amidolytic assay for factor VII: its use with a cloting assy to determine the activity state of factor 111. Blood 52: 978-988 (1978).

is Sargaritella. P.; Deutsch, E.: Clinical use of a method for the determination of factor VII by a shomogenic substrate. Thromb. Res. 21: 585-591 (14)1).

It h.hls. L.H.: Spectrophotometrische bepalingen an stollingsfactoren en fibrinolyse. Tijdschr. ned. ict klin. Chem. 6: 166-169 (1981).

Vmerson. Y.: Clyne, L.P.: An assay for coagulathin factor VII using factor VII-depleted bovine : asma. J. Lab. clin. Med. 83: 301-303 (1974).

thacn. P.A.: A quantitative one-stage method for An assa: of prothrombin. Scand. J. clin. Lab. -4si. i: 81 (1949).

Winers. H.: Preparative isolation of phosphatidylxhos trom brain. Biochim. biophys. Acta 144: $\therefore \rightarrow-\left(100^{-}\right)$.
19 Fujikawa, K.; Legaz, M.E.; Davie, E.W.: Bovine factors $X_{1}$ and $X_{2}$ (Stuart factor). Isolation and characterization. Biochemistry 11: 4882-4891 (1972).

20 Nossel, H.L.: The contact phase of blood coagulation (Blackwell Scientific Publications, Oxford 1964).

21 Osterud, B.; Rapaport, S.I.: Activation of factor IX by the reaction product of tissue factor and factor VII: additional pathway for initiating blood coagulation. Proc. natn. Acad. Sci. USA 12: 5260-5264 (1974).

22 De Kruijff, B.; Cullis, P.R.; Radda, G.K.: Differential scanning calorimetry and ${ }^{31} \mathrm{P}-\mathrm{NMR}$ studies on sonicated and unsonicated phosphatidylcholine liposomes. Biochim. biophys. Acta 406: 6-20 (1975).

23 Tans, G.; Janssen-Claessen, T.; Dieijen, G. van; Hemker, H.C.; Rosing, J. Activation of factor IX by factor XIa: a spectrophotometric assay for factor IX in human plasma. Thromb. Haemostasis 46: 256 (1981).

24 Veltkamp, J.J.; Drion, E.F.; Loeliger, E.A.: Detection of the carrier state in hereditary coagulation disorders. I. Thromb. Diath. haemorrh. 19: 279390 (1968).

25 Jonge, H.: Inleiding tot de medische statistiek, pp. 305-316 (Noordhoff, Groningen 1963).

26 Spearman, P.: The proof and measurement of association of two things. Br. J. Psychol. 2: 227-242 (1904).

27 Axelsson, G.; Korsan-Bengtsen, K.; Waldenström, $\mathrm{J}$ : : Prothrombin determination by means of a chromogenic peptide substrate. Thromb. Haemostasis 36: 517-524 (1976).

28 Bergström, K.; Egberg, N.: Determination of vitamin $\mathrm{K}$ sensitive coagulation factors in plasma. Studies on three methods using synthetic chromogenic substrates. Thromb. Res. 12: 531-547 (1978).

Received: March 12, 1982

Accepted in revised form by Editor J.C.W. van de Loo: April 27, 1982

M.P. van Dieijen-Visser,

Department of Clinical Chemistry,

De Wever Hospital, PO Box 4446 ,

NL-6401 CX Heerlen (The Netherlands) 